\title{
Stylistics of advertising texts in English and Ukrainian traditions: linguopragmatic aspect
}

\author{
E. Yu. Dubenko \\ Department of Theory and Practice of Translation from English, \\ Institute of Philology, Taras Shevchenko National University of Kyiv, Kyiv, Ukraine \\ Paper received 26.07.20; Accepted for publication 11.08.20.
}

\section{https://doi.org/10.31174/SEND-Ph2020-234VIII69-03}

\begin{abstract}
The paper presents a comparative analysis of stylistic means employed in English and Ukrainian advertising considering them from linguo-pragmatic standpoint. It aims to isolate the groups of most essential stylistic tools that secure the effectiveness of advertisement text in the two compared advertising traditions. In an interlanguage perspective, the stylistic techniques used by copywriters are indicative of certain linguo-cultural factors that give shape to those forms of advertising which have taken root in corresponding linguocultural communities. The paper focuses on both isomorphic stylistic features of English and Ukrainian advertising texts and stylistic discriminants that have established themselves in Anglo-American and Ukrainian traditions of advertising paying equal attention to the means conditioned by the factors of purely linguistic and cultural nature.
\end{abstract}

Keywords: advertisement, isomorphic stylistic features, allomorphic stylistic features, attention value, readability, memorability, selling power.

Introduction. Advertising techniques have a long-standing tradition of psycholinguistic and linguistic study in English speaking countries $[2 ; 3 ; 4 ; 5 ; 9 ; 12 ; 15 ; 16 ; 22]$ and a comparatively modest history of professional mastering in Ukraine. In Britain, the advertising industry started to grow from the mid-seventeenth century, its further progress was connected with the development of the British press in the eighteenth century and the nineteenth century industrial revolution. In the post-Second World War period an expansion of media made advertising an integral part of daily life that was gradually taking on its current recognizable form [18, p.15]. In contrast to it, the advertising industry in Ukraine has been evolved rapidly only in the twenty-first century making a gigantic step from a strictly controlled phenomenon of marginal importance it used to be before 1991 to the present day advertising art which employs an impressive volume of linguistic and visual data managing to appeal to all the senses of the consumer. The range of studies on the linguistic aspects of advertising that were performed lately by Ukrainian scholars testifies to a steady rise in attention paid to this sphere of research $[7 ; 8 ; 13 ; 20$; 21].

If English linguistic tradition has invariably treated "the language of advertising" as a separate, specific variety of language, in Slav functional stylistics the status of advertising texts remains rather dubious. The authors of "Stylistics of the Ukrainian language" regard advertising as a secondary language genre without attaching it to a particular functional style [14, p. 214]; O. Krylova maintains that advertising texts can be described conventionally as genres of publicistic speech while advertising should be treated as a complex genre of public speech that is made up of atomic genres realizing different intentions: to inform, to offer, to promise, to assure, to give hope and so on [11, p. 277-281] M.M. Kokhtev states that advertising really bears a relation on all the functional styles [10]. The latest studies on this issue give preference to the opinion that has gained currency in English tradition where the language of advertising is considered to be a special language variety [1].

Despite the absence of unanimity on this subject, the majority of scholars share the standpoint that the language of advertising is uppermost the language of commerce in view of its commercial framework and purely utilitarian purpose. According to the generic definition offered by G. Leech, the language of advertising is loaded language which differs from other types of loaded language (for example, political journalism and religious oratory) in pursuing a very precise material goal - to change the mental disposition to reach the desired kind of behaviour - to make the target audience buy a product or a service [12, p. 25]. The paramount aim of the advertisement consists in explaining the product in detail to persuade the consumer into buying it. Correspondingly, style in advertising is described as one of those five basic functions of persuasion which were elaborated by Aristotle and later classical writers and is currently treated as the linguistic stimuli used in messages. Therefore, G.Leech's fundamental study on advertising that has put forward a conceptual framework for its pragmatic and linguistic consideration appears to be topical nowadays. Its postulates have been later developed in a vast number of scholarly papers to cater for specific needs of pragmatic and linguistic investigations that address the issues of intrastyle and intralanguage communication. However, they prove to be helpful while probing some interdisciplinary fields such as interlanguage communication or translation [17], and interstyle studies, for instance, a comparative analysis of advertising and poetry [19].

The relevance of the paper is conditioned by the growing interest of both domestic and foreign linguists to the issues of advertising language in pragmatic and translational aspects. The objective of the study lies in revealing the isomorphic and allomorphic stylistic features of English and Ukrainian advertisements that are isolated in accordance with the basic criteria of persuasive advertising offered by G.Leech. The choice of Leech's classification has been prompted by its comprehensive, universal character which makes it advantageous for interlanguage comparative studies. Stylistic isomorphism in English and Ukrainian advertising texts

Many general strategies of psychological and psycholinguistic influence on the target audience are universal and fit for advertising products in any cultural tradition. Therefore, a great number of principles and methods of advertising have been extrapolated from foreign (predominantly Anglophone) advertising practice to Ukrainian market. In 
order to be effective, an advertisement in any language must meet the criteria of a successful persuasive text which, in G. Leech's classification, are termed as attention value, readability, memorability and selling power [12, p.123]. Each of these four major criteria has its consequences on the language used to achieve the corresponding purpose, accordingly, it is possible to single out four main groups of stylistic means that correlate with the criteria under discussion.

The stylistic means of the first group are associated with the attention value criterion as they fulfil the central task of any advertising text that consists in attracting attention and arousing curiosity. Attention is the initial element of a generally recognized formula AIDA (Attention, Interest, Desire, Action), that is considered to be the basic principle in the work of advertising industry. At the language level, in both advertising traditions it is achieved by breaking conventions of language use with the help of neologisms or coined words that have a special meaning in a specified context (Gordon's \& Tonic: Innervigoration. / Give a Timex to all, to all a good time. (Timex - a brand name of watch - is formed originally from the two words: "time" and "excellent") // Стильногазований напій Джинс / Зефір Жако: Жакоханість) and puns that offer a two layered meaning to the slogan (Be Cointreauversial (a campaign for the liqueur Cointreau) // Мориинська. Завжди у формі. Відтепер у новій). These stylistic means easily fascinate people with their novelty and smartness. Among other devices that put language in inappropriate or unorthodox contexts one should mention wrong spelling, grammatical solecism, rhymes and semantic deviations. All of them help to make people ponder upon the meaning and marvel at the felicitous turn of the phrase engineered by copywriters or their ingenuity as, for instance, in the following advertisement which draws its power from a creative use of repetition:

з вачими з вачими очима очима

все в порядку все в порядку.

Це подвоєння цее подвоєння

траффіку траффіку иьього року цьього року

The second group of stylistic means ensures the readability of advertisements as the interest of advertisement receivers needs to be sustained, taking into account that the reader searches for quick and simple information. Therefore, the style of advertisements is mostly informal, it suggests an easy-going social relationship between the sender of the message and the receiver, and is characterised by casual colloquial expressions, phrasal verbs, idioms, elliptic sentences and contractions: Red Bull Energy Drink: No Red Bull. No wings. I "Just like coming home..." Dedeman Hotel Service / Range Rover: It's how the smooth take the rough. // Відпадні-шоколадні, у спеку не розтануть. I МТС. На крок попереду. / В животі ураган? Приймай «Еспумізан!»

The use of slang, the elements of popular and oral speech, perjorative lexis make advertising language specially impelling, easy to understand and memorize, giving an impression that the message comes directly from the real life: You've gotta try it! // Планшетуєш? Tвій Galaxy tab 2 (Самсунг) / Не гальмуй - снікерсуй! (Нестле). Direct address to the reader, frequently with the second person pronoun "you" tends to shorten the distance between the product and the consumers. Such tactics make the receivers feel that they are the centre point of those who produce the product, and they are being taken special care of: Vogue Hair Studio: If you look good, we look good! I HYUNDAI: Always there for you. I "We speak your language" International Medical care / Trenz Hair Studio: You deserve the best. // ПриватБанк. Ваша точка опори. / TEFAL. Завжди думає про ВАC. / City Commerce Bank. Bтілює Ваші прагнення. / Індезіт. Ми працюємо - Ви відпочивасте.

The stylistic means of the third basic group found in both analyzed traditions are used to guarantee the memorability of advertisements. As it is very important that the message of an advertisement is remembered by the consumer and recognised as familiar, repetition constitutes one of the most popular advertising techniques because it enhances memorability. Different kinds of lexical, grammatical and phonetic repetition may be called the mnemonic devices that help the consumer to remember and later recall the text of the slogan or advertising. Among especially effective and, consequently, most frequently used repetitions one should mention such powerful means of memorization that keep resonating in one's mind as 1) rhyme: Drinking kills driving skills (the City of Sydney Media Center with Roads and Traffic Authority) / The flavour of a Quaver is never known to waver / V Energy: The massive hit that improves you a bit.// Альфa - cynер! Альфа клас! Альфа - стильно! Це для нас! / Читай «Експрес», вигравай Мерседес! 2) parallelism: Ford: Right people. Right components. Right prices. I Savvi Beauty Salon: Look well. Feel well. Be well. // Шалені фрукти - малений сік; 3) alliteration: TaB Energy. Fuel to be fabulous. I Greyhound: Greyhound going great. // Алан. Стандарт справжнього смаку. / Салямі мадера мрія мільярдера.

Finally, a great number of isomorphic stylistic forms in English and Ukrainian advertising texts are associated with the selling power criterion, because an effective advertisement is supposed to facilitate the customers to buy, providing clear instructions what kind of action should be taken next. Therefore imperative sentences are one of the most frequently employed means of stylistic syntax in advertising language. It is necessary to mention that both in English and Ukrainian advertising traditions imperatives often take the form of elliptical sentences or constructions with omitted subjects, that is why, usually they are not perceived as outright instructions but rather as some fragments of statements or shortened sentences: Butterfly Kisses Beauty Salon: Be bold. Be daring. Be simply beautiful.I Don't stop! Grab a Snickers! / Nike: Just do it! / Revlon: Twist. Glide. Shine. / Dodge. Grab Life by the Horns. // Iнтер Сіті. Приїжджайте! Порівнюйте! Купуйте! I Влаштуйте собі незабутнє свято! / Toуота. Керуй мрією! / Skittles. Спробуй веселку!

In general, the stylistic means that serve to provoke the positive feelings of consumers towards the product are essentially the same in English and Ukrainian advertising because, according to the doctrine of high-context and lowcontext cultures offered by Edward Hall, both English and Ukrainian cultures have similar, low-context characteristics. In Hall's way of thinking, high-context cultures have indirect character, without tendencies to discuss things; most of the information is either in physical context or internalized in the person, while little is in the coded, transmitted, explicit part of the message [6, p. 243]. Corre- 
spondingly, for instance, Japanese advertising is noted for the multifarious character of an advertising image and profound symbolism linked to the integral philosophical model of the world. Whereas low-context cultures are, on the contrary, straightforward, with a clear-cut, explicit indication of positions and the secondary role of non-verbal communication. These are, first of all, the cultures of the West, the USA and Canada. The highest index of this parameter can be observed in Germany - hence, German advertising is predominately informative, it is built on the logic of persuasion, arguments, facts, technical characteristics. It has minimal emotionality and attractive visualization (expressive video and advertising texts).

British, American and Ukrainian cultures are less lowcontext than that of Germany. For this reason they try to win consumers' hearts by a special, goal-oriented emotionality giving preference to expressive advertising images. Respectively, the customer is tempted into buying a certain product by means of: 1) striking metaphors - Estée Lauder - Sunshine bottled. I It is new Silk Gloss or am I just a love goddess? // Квартири у житловому комплексі «Кассіопея». Обери свою зірку! 2) original similes: Lightweight, extra caring formula for dry and damaged hair. Power hold and a soft touch like Cashmere. // L'orКава бездоганна, як золото; or 3) in-face hyperboles: Neutrogena - Nothing works better.l Clearasil - Acne marks can take forever to go аway. // Суп Галина Бланка, $i$ ви відуусте себе на сьомому небі. IКофе Мас Lихе: зробіть ковток, щоб відчути неперевершений аромат $i$ отримати божевільне задоволення.

It provides a prolific soil for employing various methods of manipulation on the part of advertisers, for example, glittering generalities which are highly typical of both English and Ukrainian advertising texts. These are emotionally appealing words and images associated with some highly valued concepts (desire for security, love, health, freedom, power, status, attractive appearance, ability to make friends easily). The indirect message engineered by means metaphorical or hyperbolical expressions in such advertisements consists in flattering promises of the text that buying the promoted product you are changing your life: Agna Pacific artesian mineral water. It's made in heaven. / Cedar Springs bottled water. This bottle will change your life./ Житловий комплекс Щасливий. Ми будуємо житло. Ви будуєте щуастя. All of them aim to dazzle the consumers with some fabulous characteristics of the marketed product and convince them in the positive emotions that seem to be in store for those who will buy it. In this connection there is a tendency to reify abstract notions within a framework of a metaphorical utterance which is especially obvious in Ukrainian advertising: Львівські дріжджі: Випікай любов! / Скуштуйте пориію щзастя! (advertising sweets). In a less obvious way this phenomenon manifests itself when romantic relations that typically bind human beings are presented as a romance between a person and some commercial product: Світоч: Закохайся з першого шматочка!

In both advertising traditions this manipulative strategy makes use of such weasel words as home-made, organic, fresh // натуральний, домашній, свіжій, and the so called overblown or empty adjectives with devaluated positive meaning that often make consumers adjective-blind or adjective-deaf: new, pure, magic, revolutionary // найновішій, бездоганий, феєричний, неперевершений, шалений. Compare: White Tiger, organic energy drink. From nature, naturally. I Pure, fresh mountain spring water. Bottled especially for you in Alpes from only our purest mountain springs [Evian ad campaign] // Шалениŭ обвал иін. / Шалений розпродаж. / Шалена мода для дівчат шаленої краси. / Шалені фрукти - шалений сік. / Пограбуй “Шалений Сейф” універмагу “Украӥна” на 10000 гривень. / Магазин найкращих ичін. / Ціни краще краших .

One more common method to enhance product appeal is the so called glamorisation technique which is also found in both English and Ukrainian advertising. It consists in presenting things more beautiful than they really are. Thus "old" becomes in English advertising olde, charming, characterful, unique or worlde, while Ukrainian copywriters tend to describe the old as вінтаж, ретро. The same effect may be produced by the use of glamorising euphemistic substitutions as in the following pawnshop advertisements: Речі з досвідом для практичних людей / Речі з досвідом шукають хорошого хазяїна!

Stylistic allomorphism in English and Ukrainian advertising texts. Allomorphic tendencies in English and Ukrainian advertising may rest upon the prototypical character of concrete stylistic means in one of the described traditions. It concerns, for instance, such powerful instrument of attracting the reader's attention as word-play or pun. The prevalence of this effective attention getting technique in English advertising is conditioned by certain specificities of English morphology. The English language is characterised by short, often monosyllabic or disyllabic lexical units, their polysemantism, absence of flexions, and it gives English copywriters carte blanche in playing upon the phonetic form of words. This circumstance conditions a lavish use of multiform puns in English advertisements. Word-play can be based here upon: 1) homonymy (The unique spirit of Canada. We bottled it. 'Canada' (= the name of the country) forms an association with the brand of spirits called Canada alcohol); 2) homophony (Make you every hello and good buy. 'Good buy'(= good purchase) sounds the same as 'good bye'; 3) polysemy (Face the world. 'Face' means in this advertisement from the cosmetic firm Boots Cosmetics both: a) a countenance; b) to meet with someone face-to-face); 4) association with a wellknown phrase (Sofa so good. This furniture advertising alludes to a set expression So far so good!) (Mats'kiv, 2013, p. 192).

Similarly, the abovementioned distinguishing features of English as a language system make it possible to use alliteration as a prototypical stylistic means that ensures memorability in English advertising texts. The desired effect is achieved through the use of a wide spectrum of corresponding devices (paronomasia, alliteration, assonance), because English one, two or three-syllable polysemantic lexical units can be easier converted into phonetic-semantic twins than much longer Ukrainian words complicated with numerous flexions: Eau fling. Pure Passion Perfume / ELLE Spa - We believe in the perfect harmony of serenity, service, and style / Today. Tomorrow. Toyota / Proactiv Solution - Renew, revitalize, repair and rejoice. / Redemption Salon. Where style meets exceptional service. Here is the verbal part of Dune perfume advertisement by Christian Dior which is virtually saturated with the repetitions of 
sonorants and the initial letters of both the name of the perfume (Dune) and the brand name (Dior): $\underline{\text { Dior. D }} u \underline{\text { n }} e-$

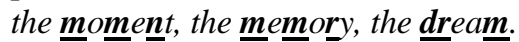

The use of foreign words in English advertising texts is rather limited. Their employment is confined solely to those cases when the marketed product represents a wellknown foreign brand invariably associated with the source nature, its culture and traditions: Dior j'adore /Cartier. L'art D'etre Unique. Jewelers since 1847/ Truc de Fau. La French energy. At the same time Ukrainian copywriters make an extensive use of not only foreign words (Water is Worth Loving. Мережа салонів сантехніки Буль-буль), but also the so called macaronic speech - mechanical mixture of words and phrases or their remaking into foreignlike language elements: Нарру середа / OLKOM - це твій STYLE життя! Обери свій STYLE! / Хрустеат: Праџююй ХАРДово, відпочивай драйвово! / Пиво Tuborg Green. Початок GREENdіозного задоволення! / CтрахOFFка. Вимкни свій страх.

Ukrainian copywriters lay special emphasis on the humorous tonality of advertisements. This tendency becomes especially obvious due to an extensive use of funny onesentence statements: Зрозуміло $i$ жирафі пити пиво краще з Даффі! (the advertisement of nuts); Ви можете дзвонити дешевше, але тільки в двері (the advertisement of discount on phone calls); Дешевше тільки пішки! (the advertisement of taxi service); А нам, як вовкам - зуби! (the advertisement of dental services).

Conclusions. Identical pragmatic aims of advertising texts in both compared cultural traditions predetermine the homologous character of stylistic forms used in English and Ukrainian advertisements. Since any effective advertisement should possess at least four key pragmatic characteristics: attention value, readability, memorability, and selling power impersonal, one may observe an array of isomorphic stylistic features responsible for securing these essential functions of a successful advertisement. Among the core stylistic means present in a vast majority of both English and Ukrainian advertising texts are: neologisms or coined words, direct address to the reader, colloquial sentences and contractions, idioms, casual colloquial expressions, phrasal verbs, different kinds of lexical, grammatical and phonetic repetition, imperative sentences, metaphors, similes and hyperboles.

However, some stylistic means employed in English and Ukrainian advertising industry do not display such unambiguous correlation. A comparative analysis of BritishAmerican and Ukrainian advertisements allows to reveal also certain divergent stylistic techniques used by advertising writers in the corresponding cultural traditions. It concerns, for instance, phonetic expressive means (alliteration, assonance, paronyms) or those stylistic differences in English and Ukrainian advertising that are conditioned by the specificities of English and Ukrainian morphology. At the same time such rather conspicuous stylistic phenomena of Ukrainian advertising discourse as foreign words and manifestations of macaronic speech do not find analogy in English.
1. Areshenkova O.Yu. (2014) Reklamnyj text jak funktsionalnyj riznovyd movlennya [Advertising text as a functional variety of speech]. Filolohichni studii. Naukovyj visnyk Kyrovohrads'koho derzh.ped.universytety. Vypusk 10. S.5-11.

2. Bovee, C.L., Arens, W.F. (1992) Contemporary advertising / C.L. Bovee, W.F. Arens. Boston: Richard D. Irwin, Inc.

3. Cook G. (2001) The discourse of advertising, $2^{\text {nd }}$ edition. London, UK: Routledge.

4. Goddard, Angela. (2002) The language of advertising: Written text. London, New York: Routledge.

5. Guidère M. (2001) Translation Practices in International Advertising. Translation Journal. Volume 5. № 1. January. http://translationjournal/15advert.htm

6. Hall, E. (1989) Beyond Culture. New York: Anchor Books.

7. Ivanova I. (2017) Model' movnoj osobystosti v ukrainomovnij reklami XXI stolittya [The model of language personality in Ukrainian advertising of the XXI century]. Intercultural communication. Vol. 1/2. pp.88-96.

8. Karpenko, H. (2016) Verbal means of persuasion in English Advertising. Journal of Vasyl Stefanyk Precarpathian National University. Vol.3. No.2-3. pp.84-87.

9. Khan R.R. (2011) Advertising/R.R. Khan, S.R. Kamble, R. Khatri, S. Lasune. Vidyanagari, Mumbai: University of Mumbai.

10. Kokhtev N.N. (1991) Stilistika reklamy [Stylistics of advertising]. M.: Izdatel'stvo Moskovskogo universiteta.

11. Krylova O.A. (2006) Lingvisticheskaya stilistika. [Linguistic stylistics] Book 1. Theory / O.A. Krylova. M.: Vyshaya shkola.

12. Leech G.N. (1972) English in Advertising. A Linguistic Study of Advertising in Great Britain. L.: Longmans.

13. Mats'kiv M.Ya. (2013) Hra sliv v anhlomovnykh reklamnykh tekstakh yak perekladats'ka problema [Play upon words in Anglophone advertising texts as a problem of translation]. Nova philologiya. № 57. pp. 191-193.

14. Mats'ko L.I. (2003) Stylistyka ukrajins'koji movy [Stylistics of the Ukrainian language] /L.I.Mats'ko, O.M.Sydorenko, O.M.Mats'ko. K.: Vyshcha shkola.

\section{ENCES}

15. Mooij, Marieke de. (2010) The Hofstede model applications to global branding and advertising strategy and research / Geert Hofstede, Marieke de Mooij. International Journal of Advertising. 29 (1). pp. $85-100$.

16. O'Donnell W.R., Loreto Todd (1991) English in Advertising. Variety in Contemporary English. Second edition. London and N.Y.: Routledge. -P. 104-118.

17. Shilina A.V. (2012) Pragmaticheskie osobennosti leksiki ol'faktornogo vospriyatiya $\mathrm{v}$ angloyazychnykh reklmnykh tekstakh i eyo perevoda na russkij yazyk [Pragmatic specificity of olphactory perception in Anglophone advertising texts and its translation into Russian). Vestnik $S P b G U$, Seriya 9. Vypusk 3. S.197-202.

18. Smith K.L. (2002) The translation of advertising texts: A study of English-language printed advertisements and their translations in Russian, V. 1. Sheffield, UK: University of Sheffield, Department of Russian and Slavonic Studies.

19. Sokolova O.V. (2013) Sovremennaya poeziya v mire reklamy: dejkticheskaya organizatsiya poeticheskikh i reklamnykh tekstov [Contemporary poetry in the world of advertising: deictic organization of poetic and advertising texts]. Vestnik RUDN. Seriya Lingvistika. № 1. S.28-36.

20. Syzonov D.Y. (2017) Stylistyka medijnoj fraseologii: slovyans'ka problematyka ta perspektyvy doslidzhennya [Stylistics of Media Phraseology: Slavonic Range of Problems and Research Perspectives]. Science and Education: a New Dimension. Philology, V (28), Issue 115. Budapest. pp. 51-54.

21. Vasyukova N.V. (2013) Teoriya relevantnosti kak kognitivnaya osnova reklamnoj komunikazii [Theory of relevance as the cognitive basis of advertising communication]. Problemy linhvistyky teksty, dyskursologii, dyskurs-analisu. Vypusk 1. S.30-33.

22. Wells W. (2000) Advertising: principles and practice / W. Wells, J. Burnett, S. Moriarty. New Jersey, USA: Prentice Hall, Upper Saddle River. http.//www.textart.ru/database/slogan/map.htm 